\title{
Distribution of dissolved free amino acids in the Ushant front region*
}

\author{
S. A. Poulet ${ }^{1}$, V. Martin-Jézéquel ${ }^{1}$ and R. N. Head ${ }^{2}$ \\ ${ }^{1}$ Centre d'Etudes d'Océanographie et de Biologie Marine, CNRS, Station Biologique, F-29211 Roscoff, France \\ ${ }^{2}$ Marine Biological Association. The Laboratory, Citadel Hill, Plymouth PL1 2PB, United Kingdom
}

\begin{abstract}
Measurements of dissolved free amino acids (DFAA) combined to phytoplankton and particulate matter parameters of water samples are described with reference to spring and summer hydrological conditions offshore the coast of Brittany in the Ushant front region. DFAA were found to exhibit vertical, lateral, diel and seasonal variations. Major differences were due to variations of a limited number of amino acids: aspartic acid, serine, histidine, threonine, glycine, alanine, leucine and ornithine. They were found to be enriched at the boundaries of the halothermoclines and the frontal region. Spectra of amino acids and total DFAA concentrations were rather similar in samples representative of mixed and stratified waters at a given season. There were no significant correlations between total DFAA concentration and phytoplankton pigments. The magnitude of seasonal and diel variations of amino acids suggest that their turnover may be related to a variety of biological, physiological and biochemical processes prevailing in the pelagic ecosystem.
\end{abstract}

\section{INTRODUCTION}

Fronts in the shelf waters of northwest Europe are boundaries between dissimilar physical environments, with plankton communities presenting relatively high biological activity (Holligan, 1981). The Ushant frontal system near the coast of Brittany extends into the western English Channel; it has been described extensively in terms of both physical (Dietrich, 1950; Pingree and Griffiths, 1978; Pingree et al, 1978) and biological (Le Fèvre and Grall, 1970; Holligan, 1981; Linley et al., 1983; Holligan et al., 1983; Le Fèvre et al., 1983) oceanography.

Among the most striking properties of this frontal system are the 2 bodies of water, warm stratified offshore and cool mixed inshore, whose positions are predictable (Pingree and Griffiths, 1978) and the boundary, which varies seasonally. Holligan et al. (1983) wrote that in the frontal regions the phytoplankton was the dominant compartment, whereas in stratified waters zooplankton biomass considerably exceeded that of the phytoplankton. Under conditions of tidal mixing an intermediate situation was observed'. Pingree et al. (1975) suggested that the

\footnotetext{
- This work is a contribution of GREPMA (Groupe Régional d'Etudes Pélagiques en Manche-Atlantique)
}

growth of phytoplankton in frontal waters resulted from the combined effects of vertical mixing and surface stabilization providing favourable nutrients and light conditions. It is also agreed that detritus, phytoplankton and bacteria tend to accumulate at density gradient boundaries such as halo- and thermoclines (Goering et al., 1970; Rheinheimer, 1974; Krause, 1981; Linley et al., 1983).

The occurrence of high phytoplankton standing stocks should be theoretically reflected in the levels of extracellular metabolites such as amino acids. However, amino acids are metabolites released by both phytoplankton (Hellebust, 1974) and zooplankton (Webb and Johannes, 1967). Their occurrence may be due also to the lysis of old cells (Hammer and Eberlein, 1981; Poulet and Martin-Jézéquel, 1983) or to leaching during 'sloppy feeding' of grazers (Lampert, 1978). They are used in heterotrophic growth and physiology of both bacteria (Amano et al., 1982) and phytoplankton (Wheeler et al., 1974; Liu and Hellebust, 1976; Bonin and Maestrini, 1981; Dortch, 1982). They are also chemical activators for several species of zooplankton crustaceans (Fuzessery and Childress, 1975; Hamner and Hamner, 1977; Poulet and Ouellet, 1982). The involvement of amino acids in various physiological and biological processes may be of importance in the dynamics of plankton communities in the frontal 
regions, where, according to Linley et al. (1983), 20 to $60 \%$ of the primary production enters the microbial food chain through dissolved components. The aim of the present study was to examine the partitioning of dissolved free amino acids (DFAA) in frontal waters.

\section{METHODS}

Positions of the stations monitored in the Ushant front regions are shown in Fig. 1. Observations were achieved during the Satir-10 cruise in the late spring (Stations A-8, 11, 13, 16: 12-13 May 1982) and during the Satir-Dynatlant cruise in the late summer (Stations 1 to $9,165,172,175,180,193,240,242$ : 11-22 September 1982). In May, temperature and salinity profiles were obtained with reversing thermometers and water samples collected with Niskin bottles, whereas, in September, a CSTD (General Oceanics) was used. At each station, water samples were collected either with 5 I Niskin bottles mounted on a rosette (General Oceanics) electrically triggered from deck, or with a submersible pump at the subsurface $(\simeq 2 \mathrm{M}$.) below the hull of the ship. Continuous records of the subsurface fluorescence were obtained with a Turner Model III Fluorometer, following the method of Holm-Hansen et al. (1965). Chlorophyll a was estimated by filtering 100 to $200 \mathrm{ml}$ of seawater onto $0.45 \mu \mathrm{m}$ membrane filters and measuring fluorescence of the $90 \%$ acetone extracts before and after the addition of acid (Yentsch and Menzel, 1963). The fluorometer was calibrated with a solution of pure chlorophyll a (Sigma Chemical Co.), the concentration of which was determined spectrophotometrically (Lorenzen, 1966). Samples for particulate organic carbon (POC) and nitrogen (PON)

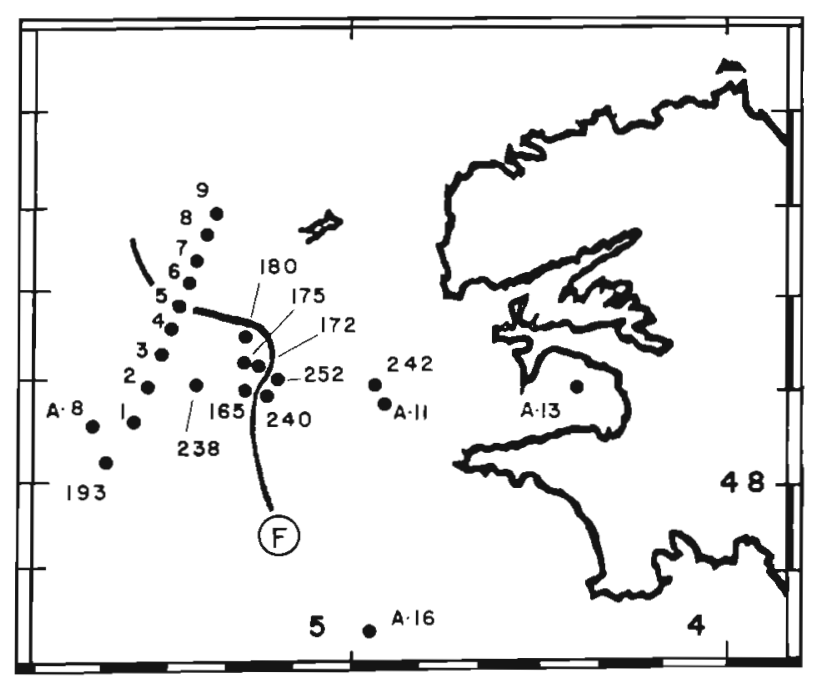

Fig. 1. Positions of stations in the Ushant front regions off the coast of Brittany. F: approximate position of front in September were obtained by screening seawater through a $200 \mu \mathrm{m}$ mesh sieve and then filtering 200 to $500 \mathrm{ml}$ through $2 \mathrm{~mm}$ Whatman GF/C glass fibre filters preashed at $450^{\circ} \mathrm{C}$ for $10 \mathrm{~h}$. Filters were stored at $-20^{\circ} \mathrm{C}$ and then oven dried at $55^{\circ} \mathrm{C}$ prior to analysis with a Carlo Erba elemental analyser (Model 1106) calibrated with cyclohexanone or $1: 5$ diphenylcarbazide standards.

Sub-samples for DFAA, $100 \mathrm{ml}$ each, were filtered gently by gravity through Whatman GF/C glass fibre filters pre-ashed at $450^{\circ} \mathrm{C}$ for $10 \mathrm{~h}$. Filtrates were collected in $6 \mathrm{ml}$ vials and stored at $-20^{\circ} \mathrm{C}$. Glassware utilized for the sampling and storage of amino acids samples were ultra-cleaned. Analysis of DFAA were performed by precolumn fluorescence derivatization with O-phthaldialdehyde using reversed-phase high performance liquid chromatography, following the method of Lindroth and Miopper (1979) and according to specific procedures already described (Poulet and Martin-Jézéquel, 1983). The HPLC was a LDC control data equipped with a LDC Flurometer Model III and a Spherisorb column type S50DS1 was used. Amino acids were identified by spiking with standards (Sigma Chemical Co.) (Fig. 2; Mopper and Lindroth, 1982).
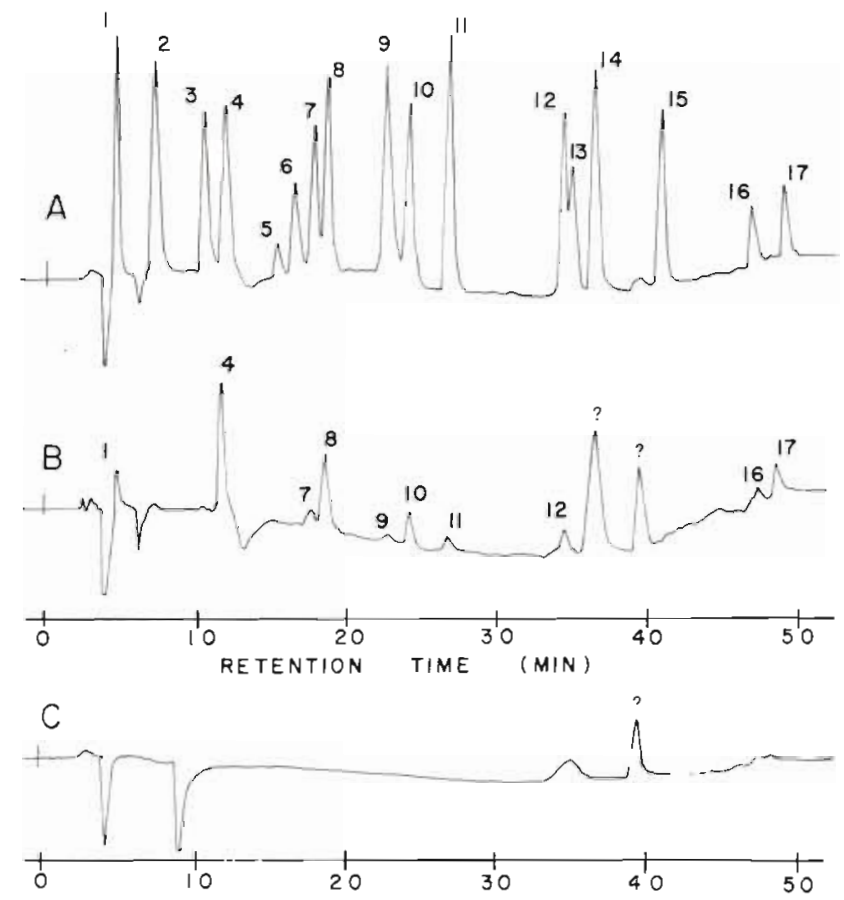

Fig. 2. Chromatograms of a standard mixture $\left.(0.20 \mathrm{pM} \mu]^{-1}\right)$ (A), and of a seawater sample (Station 180, 11.9 M) (B). 1: Aspartic acid (ASP); 2: glutamic acid (GLU); 3: asparagine $(A S N)$; 4 : serine (SER); 5: histidine (HIS); 6: glutamine (GLN); 7: arginine (ARG); 8: threonine (THR); 9: glycine (GLY); 10: alanine (ALA); 11: tyrosine (TYR); 12: triptophane (TRP); 13: valine (VAL); 14: phenylalanine (PHE); 15: leucine (LEU); 16: ornithine (ORN); 17: lysine (LYS). Peak 14 is not listed for seawater samples because of overlapping with $\mathrm{NH}_{4}^{+}$. ? = unidentified molecule. (C): Blank 
Recovery and precision representative of the method were identical to those mentioned earlier (Mopper and Lindroth, $1982 ;<10 \%$ ).

\section{RESULTS AND DISCUSSION}

Identification of the sources of DFAA in seawater is complex. In shallow estuaries, their occurrence is only partly reflected in chlorophyll a concentrations and in phytoplankton cell density, whereas macrophyte and sediment surface appeared as the major sources (Jørgensen, 1982; Macko and Green, 1982). In open waters, the situation differs and increases of DFAA concentrations during, or following, periods of high primary production are sometimes reported (Wood, 1966; Riley and Segar, 1970; Crawford et al., 1974). Excretion of nitrogen compounds by various organisms, including zooplankton crustaceans, may also contribute to the addition of non-algal amino acids (Webb and Johannes, 1967; Lampert, 1978). Liebezeit et al. (1980) found in the Sargasso Sea that dissolved organic matter was enriched at pycnocline boundaries. This phenomenon was related to the particle standing stock and to the physiological activities of phytoplankton and bacteria accumulated at the halo- and thermoclines. In the Ushant front region, observations based on physical parameters showed the kind of vertical partitioning prevailing for DFAA (Fig. 3).

In mixed waters, distribution of temperature, salinity and chlorophyll a were almost stable through the water column, whereas concentration of total DFAA varied with depth (Fig. $3 \mathrm{~A}$ ). On the other side of the front (Fig. 1), where vertical temperature-salinity gradients were sharp, both amino acids and chlorophyll a concentrations were not equally distributed with depth (Fig. $3 \mathrm{~B}$ ). It is obvious that vertical stratification of chemical and biological parameters can be modified by physical perturbations such as tidal currents and

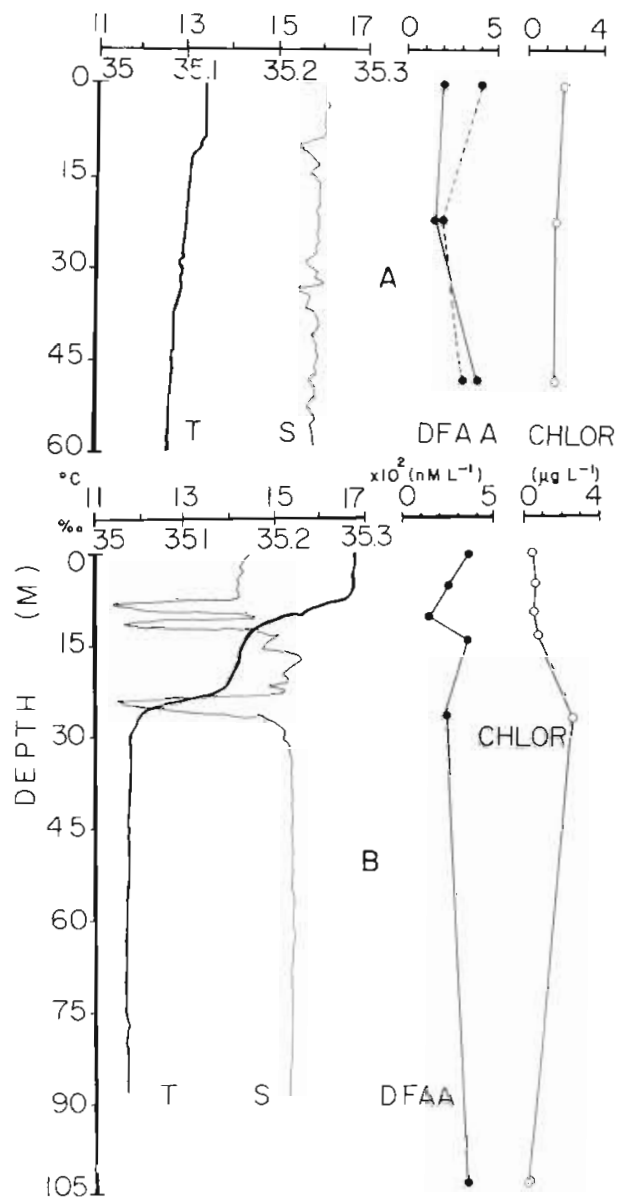

Fig. 3. Vertical profiles of temperature, salinity, chlorophyll a and total concentration of DFAA. (A) Mixed waters (Station 240: solid line; Station 252: broken line; Sep 1982). (B) Stratified waters (Station 165; Sep 1982)

mixing (Fig. 3 A). In well stratified bodies of waters, observations carried out at the $1 \mathrm{~m}$ interval in the vicinity of the physical boundary layer (Fig. 4) showed the microstructures of DFAA and chlorophyll a. Variable concentrations and enrichment of DFAA in the
Fig. 4. Vertical profiles of temperature, salinity, chlorophyll a and total DFAA concentration at the microscale level (Station 180; Sep 1982)

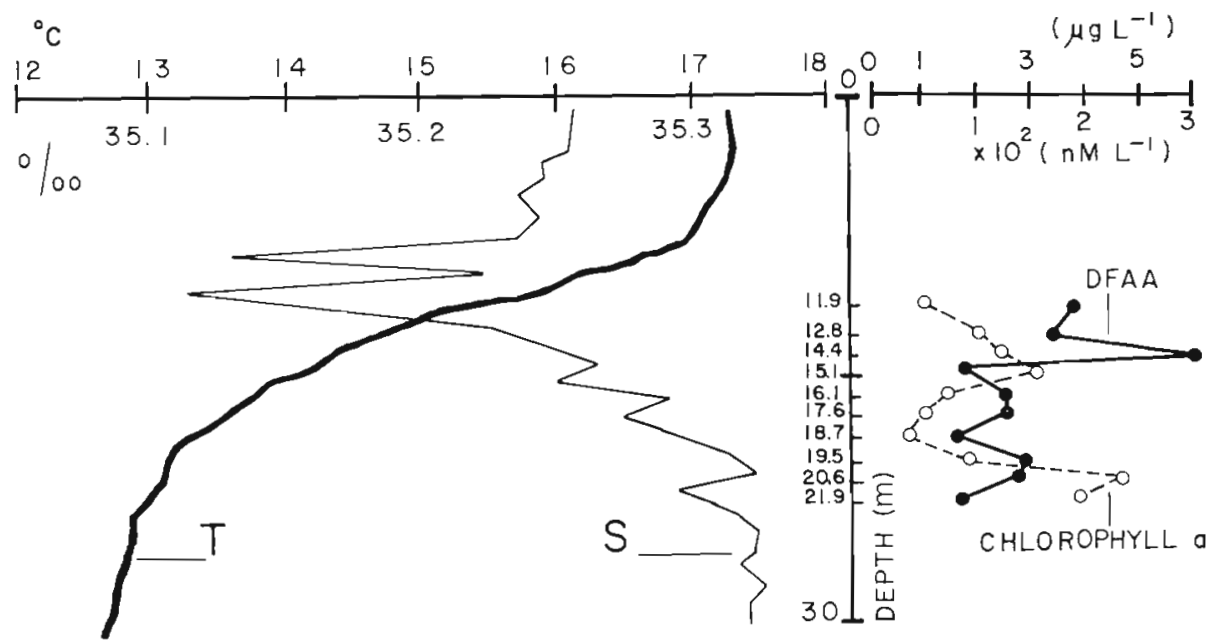


euphotic zone is a common phenomenon in the presence of vertical density gradient at the microscale level (Fig. 3 B; Liebezeit et al., 1980; Mopper and Lindroth, 1982). Other kinds of discontinuity have been reported specifically near the bottom, where DFAA also tend to increase, probably due to microbial population activity (Fig. $3 \mathrm{~B}_{\text {; }}$ Mopper and Lindroth, 1982).

On a broader spatial scale ( $>10 \mathrm{~km}$ ) the physical structures and the distribution of total DFAA were compared. Continuous records of sub-surface $(\simeq 2 \mathrm{~m})$ temperature, salinity and fluorescence, obtained when steaming across the frontal regions, are shown in Fig. 5. The concentration of chlorophyll $a$ increased towards the front and diminished in the inshore mixed waters. Highest concentrations occurred at Stations 3, 4 and 5 corresponding to the temperature-salinity boundaries on the front (Fig. 5), as reported earlier under similar conditions (Holligan, 1981). Lateral vari-

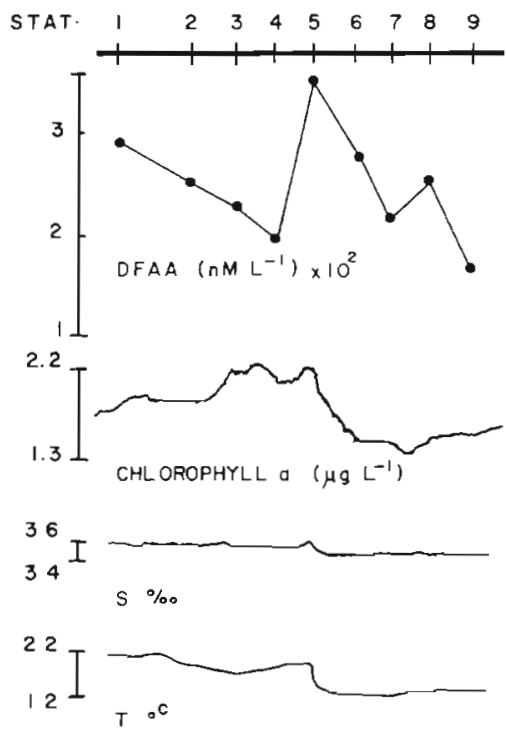

Fig. 5. Continuous records of temperature, salinity, fluorescence and distribution of total DFAA concentration in stratified, frontal and mixed waters ( $\cong 2 \mathrm{~m}$ depth; Sep 1982) ation of total DFAA concentration measured at each intermediate station did not show a trend similar to chlorophyll a although the highest value was also observed on the front at Station 5 (Fig. 1 and 5). Mixed and stratified waters could not be clearly differentiated on the basis of total DFAA concentration alone. These results contrast with the discrepancy between the 2 regions, as shown by the chlorophyll/phaeophytin and $\mathrm{C} / \mathrm{N}$ ratios, which were different on either sides of the front (Table 1).

Vertical and lateral variations of the physical structures (Fig. 3, 4 and 5) were also not reflected in the spectra of amino acids measured in the Ushant front regions. In September, the spectra were almost identical between mixed, frontal and stratified waters, at all depths, and they resembled that shown in Fig. 2 B. Serine, histidine, threonine, leucine, ornithine and lysine were the dominant amino acids in all samples. They were also the most variable in terms of concentration. Their occurrence was in agreement with the spectra of DFAA generally described in sea water (Daumas, 1976; Garrasi et al., 1979; Liebezeit et al., 1980; Dawson and Liebezeit, 1981; Jørgensen, 1982; Mopper and Lindroth, 1982). In May, mixed waters were prevailing in the entire region, nevertheless, variations of total DFAA concentrations, similar to those found in September, occurred from one station to the other. Spectra of amino acids were again identical among all samples, but they were different from those monitored during the September survey (Fig. 6). Aspartic acid, serine, glycine, threonine and alanine were, in May, the most abundant amino acids in sea water. Thus, results obtained in spring and summer suggested that occurrence of DFAA on a broad scale is partly independent of the physical structures found in the Ushant region at a given season.

Seasonal variations of the spectra have been reported earlier (Riley and Segar, 1970; Daumas, 1976; Macko and Green, 1982), One of the most striking features in comparing these authors' results obtained

Table 1. Total DFAA concentration, chlorophyll a, phaeophytin, particulate organic carbon (POC) and nitrogen (PON) in subsurface water samples $(\cong 2 \mathrm{~m}$ ) from stratified, frontal and mixed stations of the Ushant front region in September

\begin{tabular}{|cccccccc|}
\hline Station & $\begin{array}{c}\text { Chlorophyll } \\
\mu \text { I I }^{-1}\end{array}$ & $\begin{array}{c}\text { Phaeophytin } \\
\mu \mathrm{g} \mathrm{l}^{-1}\end{array}$ & $\begin{array}{c}\text { Ratio } \\
\text { Chloro/Phaeo }\end{array}$ & $\begin{array}{c}\text { POC } \\
\mu \mathrm{g} \mathrm{l}^{-1}\end{array}$ & $\begin{array}{c}\text { PON } \\
\mu \mathrm{g} \mathrm{l}^{-1}\end{array}$ & $\begin{array}{c}\text { C/N } \\
\mathrm{nM} \mathrm{I}^{-1}\end{array}$ \\
\hline 1 & 1.73 & 0.37 & 4.67 & 302.0 & 38.6 & 7.82 & 287.49 \\
2 & 2.10 & 0.39 & 5.38 & 283.2 & 36.3 & 7.80 & 252.06 \\
3 & 1.91 & 0.40 & 4.77 & 272.0 & 36.7 & 7.41 & 223.44 \\
4 & 2.09 & 0.41 & 5.09 & 248.9 & 34.1 & 7.29 & 195.60 \\
5 & 2.19 & 0.40 & 5.47 & 247.4 & 32.4 & 7.63 & 347.80 \\
6 & 1.32 & 0.49 & 2.69 & 194.8 & 23.3 & 8.36 & 277.33 \\
7 & 1.33 & 0.65 & 2.04 & 176.7 & 20.0 & 8.83 & 217.86 \\
8 & 1.35 & 0.59 & 2.28 & 184.5 & 20.2 & 9.13 & 252.90 \\
9 & 1.49 & 0.56 & 2.66 & 166.5 & 18.2 & 9.14 & 169.67 \\
\hline
\end{tabular}




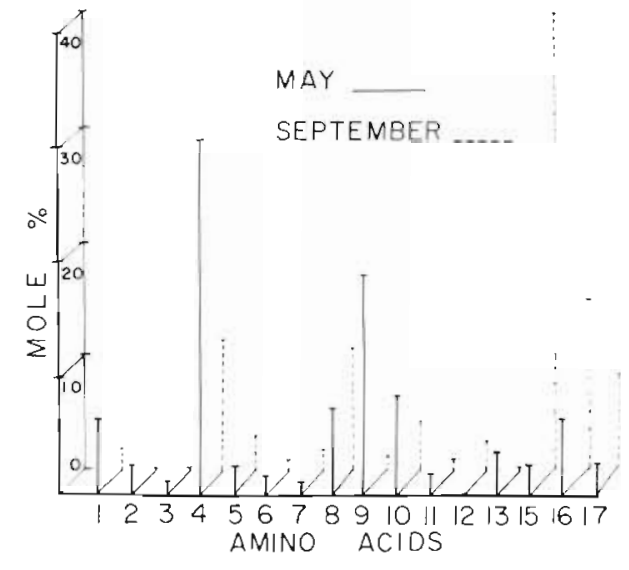

Fig. 6. Spectra of amino acids representative of sea water samples collected in the Ushant front region in May (solid line) and September (broken line) 1982. 1 to 17 as in Fig. 2. Peak 14: as in Fig. 2

from various locations, including ours in the Ushant region (Fig. $2 \mathrm{~B}$, Fig. 6), is that similar amino acids (ASP, SER, HIS, THR, GLY, ALA, LEU and ORN) are very often the most common and the most variable in sea water. Attempts to relate temporal variations of both amino acid spectra (Fig. 6) and phytoplankton species composition alone (Table 2) seems rather speculative providing that bacteria can turnover the DFAA pool in few hours (Amano et al., 1982). Although the quantity and type of each category of phytoplankton species was different between spring and summer, as were the spectra, we could not find a significant correlation between total DFAA concentration and

Table 2. Comparison of species composition and density (number cells $\mathrm{l}^{-1}$ \} of phytoplankton between 2 samples representative of spring (left: May; Station A-8; $0 \mathrm{~m}$ ) and summer (right: Sep; Station 1; $2 \mathrm{~m}$ ) conditions

\begin{tabular}{|lrr|}
\hline Nanoplankton & 175440 & 556853 \\
Chrysophyceae & & 204 \\
Dynophyceae & & \\
$\quad$ - Gymnodiniaceae & & 3876 \\
$\quad$ Gyrodinium aureolum & & 408 \\
$\quad$ - Peridiniaceae & & 2856 \\
$\quad$ Ceratiaceae & & \\
$\quad$ Ceratium spp. & 408 & 204 \\
Baccillariophyceae & & \\
$\quad$ Nitzschia periata & & 245408 \\
$\quad$ Leptocylindrus danicus & & 204 \\
$\quad$ Guinardia flacida & 2448 & 1020 \\
$\quad$ Rhizosolenia delicatula & 138720 & 204 \\
$\quad$ Chaetoceros spp. & & 612 \\
Total Baccillariophyceae & 141168 & 247448 \\
Ciliates & 8976 & 2856 \\
Total microplankton & 150552 & 257852 \\
Total & 325992 & 814705 \\
\hline
\end{tabular}

chlorophyll $a_{1}$ or chlorophyll/phaeophytin ratio $(\mathrm{n}=$ 48; $0.01<r<0.24 ; p<0.05)$. Reports of direct relations between the 2 sets of parameters are still controversial (Jørgensen, 1982; Macko and Green, 1982). The type of 'chemical print' in the water, due to amino acids related to the composition, and physiology of the phytoplankton, as shown for cultures (Hammer and Eberlein, 1981; Poulet and Martin-Jézéquel, 1983), is not so clear under field conditions. This is partly due to the high turnover of amino acids in natural environments with production being rapidly utilized by heterotrophic microorganisms (Amano et al., 1982). Fig. 7 illustrates such fast variations. Day and night samples of amino acids were collected at 4 different depths within the same water column in the euphotic zone. The water body was monitored by following a drogue set above the thermocline in the stratified zone and, thus, we assumed that samples were originating from the same body of water. Although diel variations of total DFAA concentration were small, higher changes for individual amino acid occurred depending on depth. While these variations were negligible at 13.3/12 $\mathrm{m}$ and 29.7/32 $\mathrm{m}$ (Fig. $7 \mathrm{~B}-\mathrm{D}$ ), they had higher amplitude at $6.8 / 7 \mathrm{~m}$ and $17.5 / 17 \mathrm{~m}$. At those depths, both addition of aspartic acid, serine, histidine and

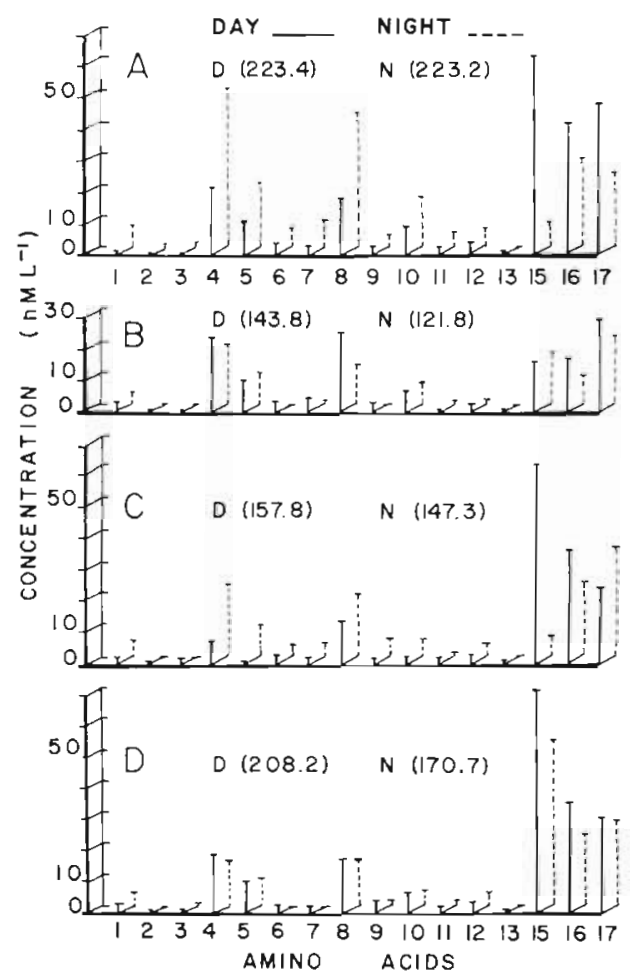

Fig. 7. Day-to-night variations of spectra and concentrations of DFAA above themocline in stratified waters at Stations 172 (D: day samples) and 175 (N: night samples). Total concentrations $\left(\mathrm{nM} \mathrm{l}^{-1}\right)$ in brackets. Depths of sampling: $\mathrm{A}=$ $6.8 / 7 \mathrm{~m} ; \mathrm{B}=13.3 / 12 \mathrm{~m} ; \mathrm{C}=17.5 / 17 \mathrm{~m} ; \mathrm{D}=29.7 / 32 \mathrm{~m}$. 1 to 17 as in Fig. 2. Peak 14: as in Fig. 2 
threonine and removal of leucine, ornithine and lysine occurred simultaneously (Fig. $7 \mathrm{~A}-\mathrm{C}$ ). In $12 \mathrm{~h}$, day-tonight differences for individual amino acids could be equal or higher than $40 \%$, whereas variations of total DFAA did not exceed $6 \%$. Similar diel variations have been reported by Mopper and Lindroth (1982).

At this stage of our knowledge, physical factors associated with the water structures found in the front regions can hardly be responsible, alone, for the distribution of dissolved organic matter (Fig. 3 to 7; Mopper and Lindroth, 1982; Holligan et al., 1983). Over a broad scale (>10 km), variations and distributions of DFAA are not likely linked to hydrological structures such as chlorophyll a in frontal regions (Pingree et al., 1975; Holligan et al., 1983). Because amino acids are labile molecules with high turn over their variations are probably due to the following factors: (1) Species composition of phytoplankton when blooming (Macko and Green, 1982). (2) Physiological stage of phytoplankton cells (Bonin and Maestrini, 1981; Hammer and Eberlein, 1981; Poulet and Martin-Jézéquel, 1983). (3) Chemical composition of particulate matter (Poulet and Martin-Jézéquel 1983). (4) Their actual source (Webb and Johanes, 1967; Jørgensen, 1982). (5) Rate of utilization by heterotrophic microorganisms (Wheeler et al., 1974; Williams and Yentsch, 1976; Dawson and Gocke, 1978; Jensen, 1983). (6) Release rate during lysis of old cells (Hammer and Eberlein, 1981; Poulet and Martin-Jézéquel, 1983), or leaching during 'sloppy feeding' of grazers (Lampert, 1978). (7) Scavenging process by metal oxyhydroxides (Mopper and Lindroth, 1982).

Further field observations need to be carefully designed in order to monitor source, concentration, distribution and turnover rates of DFAA at various scales in the pelagic ecosystem.

Acknowledgements. Thanks are due to the crew of $\mathrm{N}$. O. Noroit. We deeply appreciate the help from M. N. Guyard and $M$. Juge during preparation of the manuscript. The physical data were kindly provided by Dr. V. Mariette. This work was in part supported by CNEXO contract No. 82/6573.

\section{LITERATURE CITED}

Amano, M. S., Hara, S., Taga, N. (1982). Utilization of dissolved amino acids in seawater by marine bacteria. Mar. Biol. 68: 31-36

Bonin, D. J., Maestrini, S. Y. (1981). Importance of organic nutrients for phytoplankton growth in natural environments: implications for algal species succession. In: Platt, T. (ed.) Physiological bases of phytoplankton ecology. Can. Bull. Fish. Aquat. Sci. 210: 279-291

Crawford, C. C., Hobbie, J. E., Webb, K. L. (1974). The utilization of dissolved free amino acids by estuarine microorganisms. Ecology 55: 551-563

Daumas, R. (1976). Variations of particulate proteins and dissolved amino acids in coastal sea water. Mar. Chem. 4: 255-242

Dawson, R., Gocke, K. (1978). Heterotrophic activity in comparison to the free amino acid concentrations in Baltic Sea water samples. Oceanologia Acta 1: 45-54

Dawson, R., Liebezeit, G. (1981). The analytical methods for the characterization of organics in seawater. In: Duursma, E. K., Dawson, R. (ed.) Marine organic chemistry, Vol. 31 Elsevier, New York, p. 445-495

Dietrich, G. (1950). Die anomale Jahresschwankung des WärmeinhaIts im Englischen Kanal, ihre Ursachen und Auswirkungen. Dt. hydrogr. Z. 3: 184-201

Dortch, Q. (1982). Effect of growth conditions on accumulation of internal nitrate, ammonium, amino acids, and protein in three marine diatoms. J. exp. mar. Biol. Ecol. 61: 243-264

Fuzessery, Z. M., Childress, J. J. (1975). Comparative chemosensitivity to amino acids and their role in the feeding activity of bathypelagic and littoral crustaceans. Biol. Bull. mar. biol. Lab., Woods Hole 149: 522-538

Garrasi, C., Degens, E. T., Mopper, K. (1979). The free amino acids composition of sea-water obtained without desalting and preconcentration. Mar. Chem. 8: 31-85

Goering, J. J., Wallen, D. D., Naumann, R. M. (1970). Nitrogen uptake by phytoplankton in the discontinuity layer of the eastem subtropical Pacific ocean. Limnol. Oceanogr. 15: 789-796

Hammer, K. D., Eberlein, K. (1981). Parallel experiments with Thalassiosira rotula in outdoor plastic tanks: development of dissolved free amino acids during an algae bloom. Mar. Chem. 10: 533-544

Hamner, P., Hamner, W. M. (1977). Chemosensory tracking of scent trails by the planktonic shrimp Acetes sibogae australis. Science, N. Y. 195: 881-888

Hellebust, J. A. (1974). Extracellular products. In: Stewart, N. D. (ed.) Algal physiology and biochemistry. University California, p. 838-863

Holligan, P. M. (1981). Biological implications of fronts on the northwest European continental shelf. Phil. Trans. R. Soc. (Ser. A) 302: 547-562

Holligan, P. M., Harris, R. P., Newell, R. C., Harbour, D. S., Head, R. N., Linley, E. A. S., Lucas, M. I., Tranter, P. R. G. (1983). The partitioning of organic carbon in mixed, frontal and stratified waters of the English channel. Mar. Ecol. Prog. Ser. 14: 111-127

Holm-Hansen, O., Lorenzen, C. J., Holmes, R. W., Strickland, J. D. H. (1965). Fluorometric determination of chlorophyll. J. Cons. int. Explor Mer 30: 3-15

Jensen, L. M. (1983). Phytoplankton release of extracellular organic carbon, molecular weight composition and bacterial assimilation. Mar. Ecol. Prog. Ser. 11: 39-48

Jørgensen, N. O. G. (1982). Heterotrophic assimilation and occurrence of dissolved free amino acids in a shallow estuary. Mar. Ecol. Prog. Ser. 8: 145-159

Krause, M. (1981). Vertical distribution of fecal pellets during flex 76. Helgoländer Meeresunters. 34: 313-327

Lampert, W. (1978). Release of dissolved organic carbon by grazing zooplankton. Limnol. Oceanogr. 23: 831-834

Le Fèvre, J., Grall, J. R. (1970). On the relationships of Noctiluca swarming of the western coasts of Brittany with hydrological features and plankton characteristics of the environment. J. exp. mar. Biol. Ecol. 4: 287-306

Le Fèvre, J., Viollier, M., Le Corre, P., Dupouy, C., Grall, J. R. (1983). Remote sensing observations of biological material by LANDSAT along a tidal thermal front and their relevancy to the available field data. Estuar coast. Shelf Sci. 16: $37-50$ 
Liebezeit, G., Bölter, M., Brown, I. F., Dawson, R. (1980). Dissolved free amino acids and carbohydrates at pycnocline boundaries in the Sargasso Sea and related microbial activity. Oceanologica Acta 3: 357-362

Lindroth, P., Mopper, K. (1979). High performance liquid chromatographic determination of subpicomole amounts of amino acids by precolumn fluorescence derivatization with O-Phthaldialdehyde. Anal. Chem. 51: 1667-1674

Linley, E. A. S., Newell, R. C., Lucas, M. I. (1983). Quantitative relationships between phytoplankton, bacteria and heterotrophic microflagellates in shelf waters. Mar. Ecol. Prog. Ser. 12: 77-89

Liu, M. S., Hellebust, J. A. (1974). Uptake of amino acids by the marine centric diatom Cyclotella cryptica. Can. J. Microbiol. 20: 1109-1118

Lorenzen, C. J. (1966). A method for the continuous measurements of in vivo chlorophyll concentration. Deep Sea Res. 13: $223-227$

Macko, S. A., Green, E. J. (1982). An investigation of the dissolved free amino acids and their relation to phytoplankton cell density in the Damariscotta river estuary, Maine. Estuaries 5: 68-73

Mopper, K., Lindroth, P. (1982). Diel and depth variations in dissolved free amino acids and ammonium in the Baltic Sea determined by shipboard HPLC analysis. Limnol. Oceanogr. 27: 336-347

Pingree, R. D., Pugh, P. R., Holligan, P. M., Forster, G. R. (1975). Summer phytoplankton blooms and red tides in the approaches to the English Channel. Nature, Lond. 258: 672-677

Pingree, R. D., Griffiths, D. K. (1978). Tidal fronts on the shelf seas around the British Isles. J. geophys. Res. 83: $4615-4622$

Pingree, R. D., Holligan, P. M., Mardell, G. T. (1978). The effects of vertical stability on phytoplankton distributions in the summer on the northwest European shelf. Deep Sea Res. 25: 1011-1028

Poulet, S. A., Ouellet, G. (1982). The role of amino acids in the chemosensory swarming and feeding of marine copepods. J. Plankt. Res. 4: 341-361

Poulet, S. A., Martin-Jézéquel, V. (1983). Relationships between dissolved free amino acids, chemical composition and growth of the marine diatom Chaetoceros debile. Mar. Biol. 77: 93-100

Rheinheimer, G. (1974). Bakterien. In: Magaard, L. Rheinheimer, G. (ed.) Meereskunde der Ostsee. Springer, Berlin, p. 161-170

Riley, J. P., Segar, D. A. (1970). The seasonal variations of the free and combined dissolved free amino acids in the Irish Sea. J. mar. biol. Ass. U. K. 50: 713-720

Webb, K. L., Johannes, R. E. (1967). Studies of the release of dissolved free amino acids by marine zooplankton. Limnol. Oceanogr. 12: 376-382

Wheeler, P. A., North, B. B., Stephens, G. G. (1974). Amino acids uptake by marine phytoplankters. Limnol. Oceanogr. 19: 249-259

Williams, P. J. Le B., Yentsch, C. S. (1976). An examination of photosynthetic production, excretion of photosynthetic products, and heterotrophic utilization of dissolved organic compounds with reference to results from a coastal subtropical sea. Mar. Biol. 35: 31-40

Wood, L. (1966). Determination of free amino acids in seawater. In: Scova, N. B., Silvio, B., Bardon, E. (ed.) Automation in analytical chemistry. Technicon Symposium. Mediad Inc, New York, p. 625-655

Yentsch, C. S., Menzel, D. W. (1963). A method for the determination of phytoplankton chlorophyll and phaeophytin by fluorescence. Deep Sea Res. 10: 221-231

This paper was submitted to the editor; it was accepted for printing on March 19, 1984 